\title{
A genomic analysis of Mycobacterium immunogenum strain CD11_6 and its potential role in the activation of T cells against Mycobacterium tuberculosis
}

Gurpreet Kaur ${ }^{1,6+}$, Atul Munish Chander ${ }^{2,3,7 \dagger}$, Gurwinder Kaur ${ }^{4}$, Sudeep Kumar Maurya', Sajid Nadeem', Rakesh Kochhar ${ }^{5}$, Sanjay Kumar Bhadada $2^{*}$, Javed N. Agrewala ${ }^{1,6^{*}}$ (D) and Shanmugam Mayilraj $j^{4,8^{*}}$

\begin{abstract}
Background: Mycobacterium tuberculosis (Mtb) is an etiological agent of tuberculosis (TB). Tuberculosis is a mounting problem worldwide. The only available vaccine BCG protects the childhood but not adulthood form of TB. Therefore, efforts are made continuously to improve the efficacy of BCG by supplementing it with other therapies. Consequently, we explored the possibility of employing Mycobacterium immunogenum (Mi) to improve BCG potential to protect against Mtb.

Results: We report here the genome mining, comparative genomics, immunological and protection studies employing strain CD11_6 of Mi. Mycobacterium immunogenum was isolated from duodenal mucosa of a celiac disease patient. The strain was whole genome sequenced and annotated for identification of virulent genes and other traits that may make it suitable as a potential vaccine candidate. Virulence profile of Mi was mapped and compared with two other reference genomes i.e. virulent Mtb strain H37Rv and vaccine strain Mycobacterium bovis (Mb) AFF2122/97. This comparative analysis revealed that Mi is less virulent, as compared to Mb and Mtb, and contains comparable number of genes encoding for the antigenic proteins that predict it as a probable vaccine candidate. Interestingly, the animals vaccinated with Mi showed significant augmentation in the generation of memory $T$ cells and reduction in the Mtb burden.
\end{abstract}

Conclusion: The study signifies that Mi has a potential to protect against Mtb and therefore can be a future vaccine candidate against TB.

Keywords: Mycobacterium immunogenum (Mi), Mycobacterium tuberculosis (Mtb), Mycobacterium bovis (Mb), Whole genome sequencing, Immune response, T cell memory

\footnotetext{
*Correspondence: bhadadask@rediffmail.com; jagrewala@gmail.com; mayilrajs@bentoli.com

${ }^{\dagger}$ Gurpreet Kaur and Atul Munish Chander contributed equally to this work.

${ }^{2}$ Department of Endocrinology, Post Graduate Institute of Medical Education and Research, Chandigarh, India

'Immunology Laboratory, CSIR- Institute of Microbial Technology,

Chandigarh, India

${ }^{4}$ Microbial Type Culture Collection and Gene bank (MTCC), CSIR- Institute of

Microbial Technology, Chandigarh, India

Full list of author information is available at the end of the article
}

(c) The Author(s). 2019 Open Access This article is distributed under the terms of the Creative Commons Attribution 4.0 International License (http://creativecommons.org/licenses/by/4.0/), which permits unrestricted use, distribution, and reproduction in any medium, provided you give appropriate credit to the original author(s) and the source, provide a link to the Creative Commons license, and indicate if changes were made. The Creative Commons Public Domain Dedication waiver (http://creativecommons.org/publicdomain/zero/1.0/) applies to the data made available in this article, unless otherwise stated. 


\section{Background}

The treatment and control of tuberculosis (TB) is a growing challenge worldwide due to emerging multi-drug resistant strains of Mycobacterium tuberculosis (Mtb), failure of BCG vaccine and AIDS pandemic. BCG is a controversial vaccine since its protective efficacy varies from 0 to $85 \%$ [1-3]. Although, maximum number of people have been vaccinated with BCG worldwide, yet TB continues to afflict the global population. The vaccine protects the childhood but not adulthood manifestation of the disease. Extensive clinical trials conducted at Chengalpattu, Tamil Nadu, India suggested that BCG failed to protect TB-endemic population $[4,5]$. Development of a safe and efficacious vaccine against $\mathrm{TB}$ has been recognized as an immediate global priority by the WHO. Alternative TB vaccines based on a BCG platform, or novel approaches to supplement BCG with agents that could enhance its efficacy, could be useful to combat TB in future. One of the many reasons for the failure of BCG vaccine is its inability to generate $\mathrm{CD} 8 \mathrm{~T}$ cell response and to elicit long-lasting memory T cells $[6,7]$. The earliest principles of vaccinology involves use of attenuated pathogens to allow its safe administration. Killed whole-cell mycobacterial vaccines may be a potential strategy for successful TB vaccine development. Seventy years ago, inactivated whole-cell mycobacterial vaccines administered in multiple-doses have shown protective efficacy in experimental models, as well as humans, but were not developed further after the discovery of BCG [8]. A prominent example is Mycobacterium vaccae ('Vaccae'), a heat-inactivated whole-cell vaccine against TB, which is already being approved in China for the adjunct treatment of TB [9]. Mycobacterium immunogenum (Mi) is a non-tuberculous mycobacterium that is associated with hypersensitivity pneumonitis (HP). We did not observe any report demonstrating the role of $M i$ in protection against $M t b$. The $M i$ strain CD11_6 was isolated from duodenal mucosa of a celiac disease (CD) patient. The strain was sequenced for determining its probable role in pathogenesis of $\mathrm{CD}$, as microbes are known to play an important role in celiac autoimmunity [10-14]. The genomic annotations of $M i$ indicates that it possesses fewer virulence genes, as compared to BCG and target organism $M t b$. Further, our in-silico studies indicate that it has sufficient antigenic repertoire; suggesting that it has enough potential to protect against $M t b$. Sequence of $M i$ suggested that 16 out of total 26 peptides from $M t b$ showed sequence homology ranging $57-100 \%$ with similar cell surface proteins or secretory proteins of CD11_6 (Mi). Further, prior published literature suggests a probable role of $M i$ in eliciting immune response [15, 16]. This preliminary information had derived our interest to explore protective efficacy of $M i$ against $M t b$. Keeping in view of above mentioned facts, we adjudged to use heat killed $M i$ as a vaccine candidate and check its efficacy against $M t b$. The present study indicates that $M i$ can induce optimum activation of both CD4 $\mathrm{T}$ cells and CD8 T cells. Further, enhancement in the pool of memory $\mathrm{T}$ cells was noticed, as indicated by modulation in the expression of the memory markers CD44, CD127 and CD62L. Consequently, this signifies a possible use of $M i$ as a vaccine candidate against $M t b$.

\section{Results \\ Characterization and phylogenetic analysis of strain CD11_6}

The Mi strain designated as CD11_6 had matched with most of the phenotypic (Gram-positive, aerobic, rods in shape, acid fast, non-motile) characteristics of the genus Mycobacterium and most of the other features matched with the species M. immunogenum (Mi): negative for nitrate reduction, utilization of citrate; positive for D-glucitol, i-myo-inositol, and D-mannitol. Antimicrobial test of $M i$ showed susceptibility to amikacin, clarithromycin and resistant to cefoxitin, cefmetazole, ciprofloxacin, doxycycline, imipenem, sulfamethoxazole and tobramycin. 16S rRNA gene sequence showed that the strain CD11_6 correspond to the genus Mycobacterium and is most closely related to M. immunogenum CCUG $47286^{\mathrm{T}}$ (99.93\% identity) followed by Mycobacterium abscessus subsp. bolletii $\mathrm{BD}^{\mathrm{T}}$ and Mycobacterium abscessus subsp. abscessus ATCC $19977^{\mathrm{T}}$ (99.56\%), Mycobacterium saopaulense EPM10906 ${ }^{\mathrm{T}}$ (99.49\% identity), Mycobacterium franklinii $\mathrm{CVOO2}^{\mathrm{T}}$ (99.42\% identity), Mycobacterium chelonae ATCC $35752^{\mathrm{T}}$ (99.42\% identity) and Mycobacterium salmoniphilum ATCC $13758^{\mathrm{T}}$ (99.42\% identity). A collective phylogenetic tree comprising of Neighbor joining (NJ), Maximum likelihood (ML) and Maximum parsimony (MP) of strain CD11_6 was constructed using the 16S rRNA gene sequences of the most closely related species for the genus Mycobacterium. Strain CD11_6 formed a separate branch with Mi DSM $44764^{\mathrm{T}}$ (Fig. 1).

\section{Genome features}

The draft genome of strain CD11_6 consisted of $5,272,194$ bp with $\mathrm{G}+\mathrm{C}$ content $64.4 \mathrm{~mol} \%$, 5104 predicted CDS, 398 sub-systems and 59 RNAs. The final assembly contained 35 contigs with $\mathrm{N}_{50}$ contig length of $369,643 \mathrm{bp}$ and the largest contig assembled was measured 1,437,452 bp. CD11_6 (Mi) genome was the largest $(5.2 \mathrm{Mb})$ among the genome of $M t b(4.3 \mathrm{Mb})$ and $M b$ (4.4 Mb). Both strains $M t b$ and $M b$ had $65.6 \%$ genomic $\mathrm{G}+\mathrm{C}$ content whereas $M i$ had $64.4 \%$. Other genome features of strain CD11_6 along with two reference genomes are shown in Table 1. 


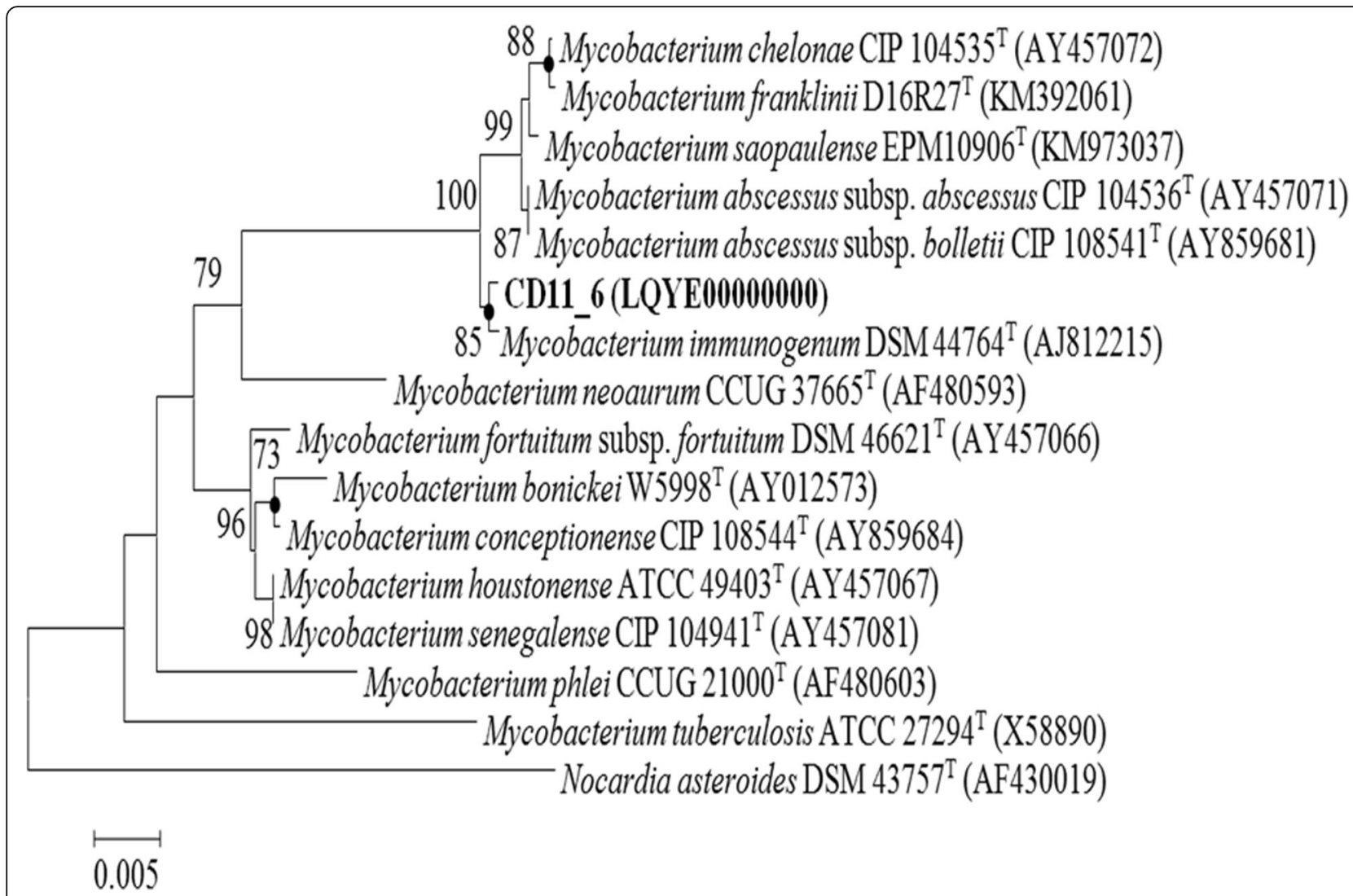

Fig. 1 Neighbour-joining tree based on 16S rRNA gene sequences, showing the phylogenetic relationship between the strain CD11_6 and other related members of the genus Mycobacterium. Nocardia asteroides DSM $43757^{\top}$ (AF430019) was used as an out group. Bootstrap values (expressed as percentage of 100 replications) greater than $70 \%$ are given at the nodes. Filled circles indicate that corresponding nodes were also recovered in the trees generated with maximum parsimony and maximum likelihood algorithms. Bar $0.01 \%$ sequence variation

Table 1 Genome features of strain CD11_6 and other reference strains of genus Mycobacterium

\begin{tabular}{llll}
\hline Organism & $\begin{array}{l}\text { Mycobacterium immunogenum } \\
\text { strain CD11_6 }\end{array}$ & $\begin{array}{l}\text { Mycobacterium tuberculosis } \\
\text { strain H37Rv }\end{array}$ & $\begin{array}{l}\text { Mycobacterium bovis strain } \\
\text { AFF2122/97 }\end{array}$ \\
\hline Accession number & LQYE00000000.1 & NC_000962.3 & NC_002945.4 \\
Isolation source & Duodenal mucosa of CD patient & Human sputum & Diseased Cow \\
Size (Mb) & 5.27 & 4.41 & 4.35 \\
Contigs & 35 & 1 & 1 \\
Scaffold & 32 & 1 & 1 \\
G+C & 64.4 & 65.6 & 65.6 \\
tRNA & 56 & 46 & 45 \\
Other RNA & 3 & 22 & 2 \\
Number of RNA's & 59 & 48 & 48 \\
Genes & 5112 & 4008 & 4001 \\
Proteins & 5000 & 3906 & 3918 \\
Pseudogenes & 50 & 30 & 33 \\
Number of subsystem & 398 & 400 & 401 \\
Coding sequences & 5104 & 4249 & 4175
\end{tabular}




\section{Genome comparison}

\section{Draft genome visualization using BRIG}

By using BRIG software that works based on BLAST, a circular comparative map of whole genome was generated as concentric rings. This map shows genome sequence in the form of concentric rings. Darker areas of rings represent $100 \%$ sequence similarity with the reference genome but lighter (grey) areas represent $70 \%$ sequence similarity. Upper and lower thresholds for sequence identity were set as $90 \%$ and $70 \%$, subsequently.

BRIG based sequence analysis among three strains was carried out. Initially, genome of H37Rv-Mtb was considered as the reference and two coloured concentric rings represent comparative level of similarity in genomes of strain AFF2122/97-Mb and strain CD11_6 (Mi) (Fig. 2). First dark blue concentric ring from centre represents genome of AFF2122/97- $M b$ and its sequence comparison with $\mathrm{H} 37 \mathrm{Rv}-M t b$, whereas second concentric ring represents $M i$ and its sequence comparison with H37Rv-Mtb. Genome sequence of AFF2122/97-Mb resembles more closely with $\mathrm{H} 37 \mathrm{Rv}-M t b$, as represented by the dark blue circle surrounding $M t b$ reference genome. However, genome sequence of $M i$ also shows sequence homology with genome of $\mathrm{H} 37 \mathrm{Rv}-M t b$, as represented by several dark blue bands in the outermost circle. Therefore, it can be surmised that the genome of $M i$ may code for similar proteins like of $M t b$ and thus can be a potent vaccine candidate against $M t b$. Similarly, Fig. 3 represents the comparative sequence analysis of strain CD11_6 (Mi), with strain AFF2122/97-Mb as a reference. Light bands in the concentric ring represent levels of dissimilarity whereas the dark coloured patches represent similarity with the reference genome. The map shows that genome sequence of $M i$ is very similar to that of AFF2122/97- $M b$, already a vaccine strain being used against $M t b$. BRIG map indicated genomic similarities but actual predictions can be attained by knowing about the coded proteins. Thus, the genomic similarities were further validated by annotating genomes of all the strains in RAST server and a comparison was established.

\section{Comparison of relevant virulence determinants}

In RAST server, genes are grouped into categories according to their major role in living systems. As per specific functions of genes, each category is divided into

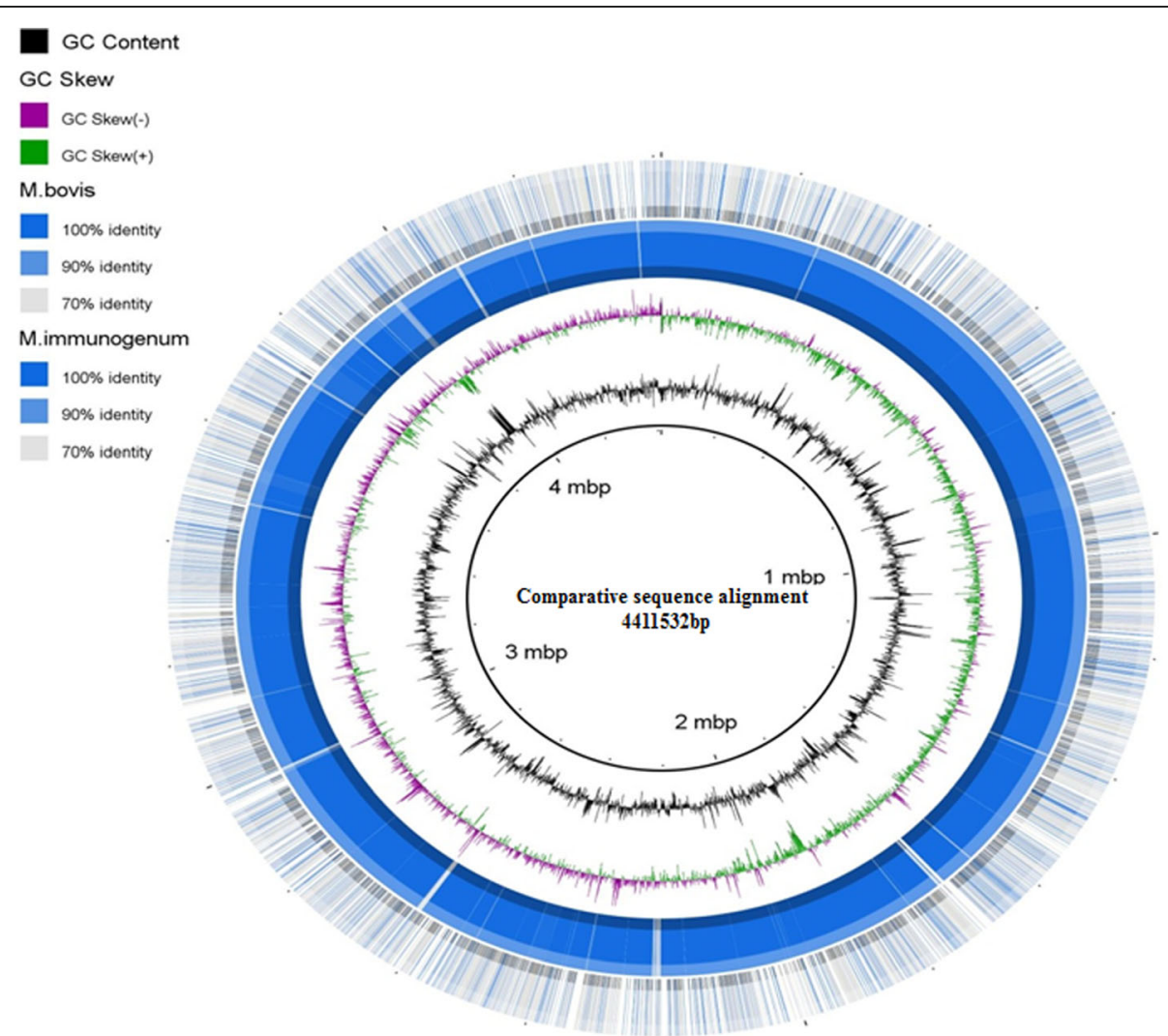

Fig. 2 Genome sequence comparison of all the three strains. The innermost dark circle represents the reference genome of strain $\mathrm{H} 37 \mathrm{Rv}$ (Mtb), the dark blue circle surrounding reference genome belongs to strain AFF2122/97 (Mb) and the outermost blue circle with white patches denotes genome of strain CD11_6 (Mi). The circles lying in between the reference genome and genome of strain AFF2122/97 (Mb) represents GC content (black coloured) and GC skew (dual coloured lines) 


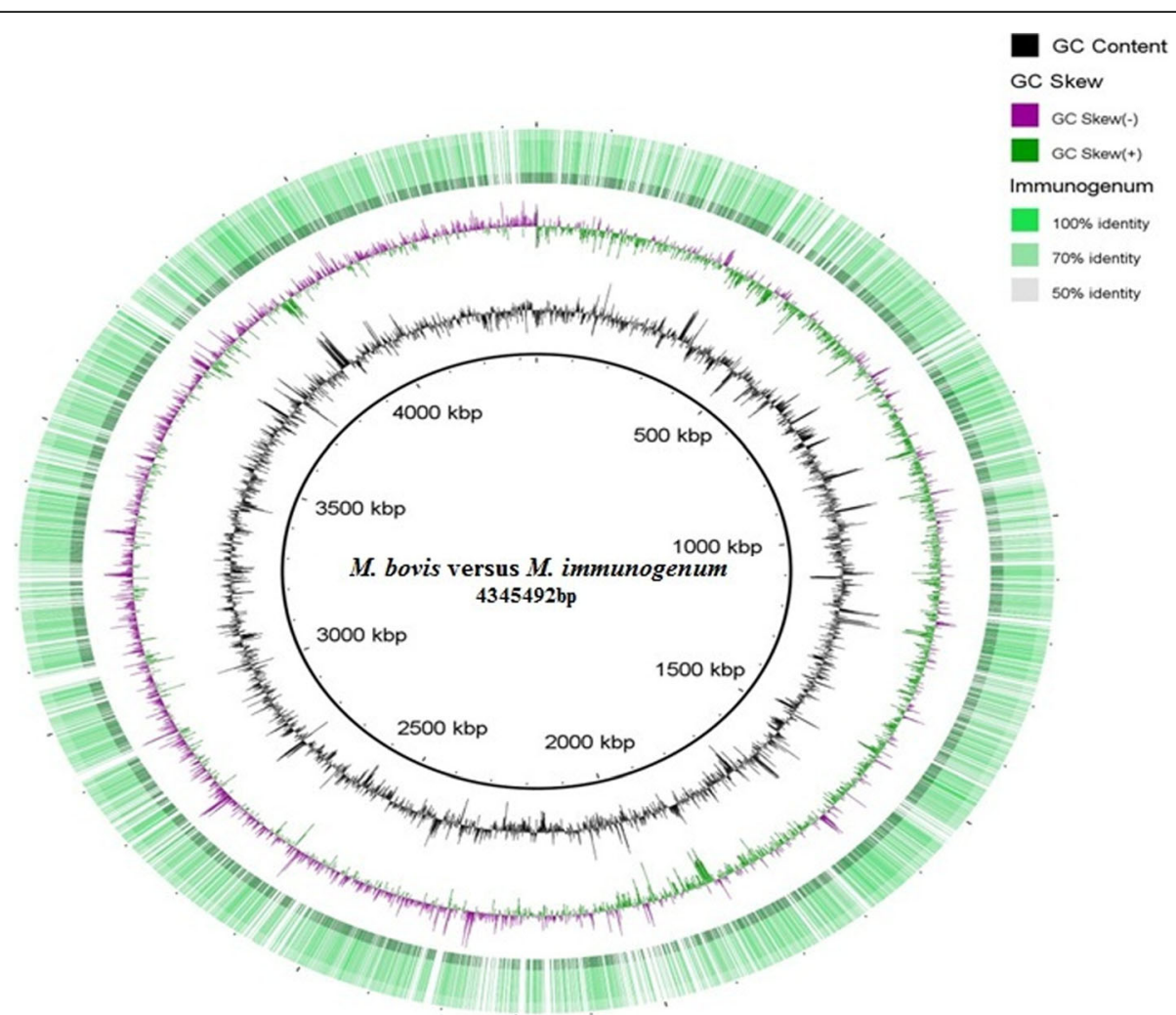

Fig. 3 Genome sequence comparison of Mb and Mtb. Genome sequence comparison of strain AFF2122/97 (Mb) and strain CD11_6 (Mi). The innermost dark circle is the reference genome of strain AFF2122/97 (Mb), the outermost green circle denotes strain CD11_6 (Mi). Like Fig. 2, the circles lying in between the reference genome and genome of strain CD11_6 (Mi) represents GC content and GC skew

sub-categories which are further divisible into subsystems with a set of genes. Genome comparison of strain CD11_6 (Mi), was carried out with strains $\mathrm{H} 37 \mathrm{Rv}-M t b$ and AFF2122/97-Mb. The analysis revealed various categories of genes, among which virulence, disease and defence (VDD), iron acquisition and metabolism, membrane transport proteins, genes of phages, prophages and transposable elements, genes involved in stress response were further studied because of their extreme importance to evaluate the status of strain CD11_6 as a vaccine candidate. As per relevance, we studied two subcategories of VDD i.e. i] resistance to antibiotics and toxic compounds; ii] invasion and intracellular resistance.

\section{Genes involved in virulence disease and defence (VDD)}

For the category VDD, a total of 66 genes were present in the three genomes. Thirty six genes were common in three genomes. Interestingly, $\mathrm{H} 37 \mathrm{Rv}-M t b$ and AFF2122/ 97-Mb had 61 genes but CD11_6 had 41 genes. Thus, CD11_6 lacks 21 virulence factor genes of category VDD, compared to other two strains but contains almost common membrane proteins with H37Rv and AFF2122/ 97 (Table 2). The fact is in favour of $M i$ as an attenuated vaccine candidate that has lesser virulence factors than the target pathogen but has comparable number of same membrane proteins like the target organism $(M t b)$ and the well-established vaccine strain $(M b)$. In addition to the common membrane proteins, the strain CD11_6 (Mi) contains 3 unique membrane proteins whereas strain AFF2122/97 $(M b)$ had 2 unique genes. Subcategory "invasion and intracellular resistance" of VDD is most relevant because of the membrane associated proteins responsible for virulence that can act as vaccine candidate proteins. In all 47 genes in this subcategory, $\mathrm{H} 37 \mathrm{Rv}$ had 10 genes coding for membrane proteins (Table 2). Strain AFF2122/97 had total 9 of these genes. Strain CD11_6 (Mi) had 6 genes common with AFF2122/97 and H37Rv. Thus, CD11_6 (Mi) contains almost similar membrane proteins like the target organism and $M b$. In the next sections, we predicted the potential of strain CD11_6 (Mi), as a suitable candidate for vaccination against $M t b$.

\section{Genes involved in invasion and intracellular resistance}

In this sub-category, strain $\mathrm{H} 37 \mathrm{Rv}-\mathrm{M} t b$ had 48 genes, strain AFF2122/97-Mb had 46 genes and strain CD11_6 (Mi) had 27 genes. Out of total 48 genes, 27 are common in all. Unlike other two strains, CD11_6 (Mi) does not contain any gene for PPE gene cluster, mycobacterium virulence operon with PE family; ESAT-6-like proteins, 
Table 2 Representation of common membrane proteins in all organisms

\begin{tabular}{|c|c|c|c|c|}
\hline S.No & Name of membrane proteins & Mi & Mtb & $M b$ \\
\hline 1. & Inner membrane protein translocase component YidC, long form & Y & Y & Y \\
\hline 2. & Conserved hypothetical integral membrane protein YrbE1A & Y & Y & Y \\
\hline 3. & Conserved hypothetical integral membrane protein YrbE1B & Y & Y & Y \\
\hline 4. & MCE-family lipoprotein LprK (MCE-family lipoprotein Mce1e) & Y & Y & Y \\
\hline 5. & MCE-family protein Mce1B & Y & Y & Y \\
\hline 6. & Fig. 025093: Probable membrane protein & Y & Y & Y \\
\hline 7. & Fig. 030769: Probable conserved MCE associated membrane protein & $\mathrm{N}$ & Y & Y \\
\hline 8. & Type VII secretion integral membrane protein EccD & $\mathrm{N}$ & Y & N \\
\hline 9. & Fig. 033285: Conserved MCE associated transmembrane protein & $\mathrm{N}$ & Y & Y \\
\hline 10. & Fig. 033430: Probable conserved MCE associated membrane protein & $\mathrm{N}$ & Y & Y \\
\hline
\end{tabular}

$\mathrm{Y}$ : presence of a gene; $\mathrm{N}$ : absence of a gene

and mycobacterium virulence operon in an unknown function with superoxide dismutase (Fig. 4). For all other gene functions, strain CD11_6 (Mi) had equal or less genes compared to strain H37Rv-Mtb and AFF2122/97-Mb supporting the low virulence attributes of strain CD11_6.

PPE proteins, early-secreted antigen target (ESAT-6) like proteins and the $10-\mathrm{kDa}$ culture filtrate protein (CFP10) are the product of region of deletion 1 (RD1) [17]. RD1 codes for 9 genes and most of them are responsible for virulence and pathogenesis [18].

In the sub-category, invasion and intracellular resistance, the presence of subsystem mycobacterium virulence operon was observed in $M t b$ and $M b$ that contains ESAT-6- like proteins (ESAT-6-like protein EsxL and ESAT-6-like protein EsxK), whereas $M i$ lacks such genes. During BLAST search analysis in the genomes, $6 \mathrm{kDa}$ early secretory antigenic target ESAT-6 (EsxA) was also reported to be present in $M t b$ and $M b$ but not in $M i$. These associated genes are responsible for virulence in $M t b$ [19]. The presence of CFP-10 was observed both in $M t b$ and $M b$ but not in $M i$. The lack of such genes in $M i$ validates it even safer than $M b$.

\section{Genes involved in resistance to antibiotics and toxic compounds}

Genes responsible for resistance to antibiotics and toxic compounds enable organisms to survive in adverse clinical environments. Strain CD11_6 (Mi) encoded 14 genes, H37Rv-Mtb had 13 genes and AFF2122/97-Mb had 11 genes in this subcategory (Fig. 5). Like other strains, CD11_6 possess same 2 genes that can cause resistance to fluoroquinolones. CD11_6 (Mi) had 4 genes that can be responsible for resistance against beta-lactam antibiotics and 3 of these genes were also common in other 2 strains. Gene coding for metal-dependent hydrolases of the beta-lactamase superfamily III is unique in CD11_6, whereas gene coding for enzyme beta-lactamase class A was absent in CD11_6, but common in strains AFF2122/ 97- $M b$ and $\mathrm{H} 37 \mathrm{Rv}-M t b$.

\section{Predictions for immunization potential of Mi CD11_6 against Mtb}

Immunization potential of strain CD11_6 (Mi) against $\mathrm{H} 37 \mathrm{Rv}-M t b$ was predicted using computational approaches. Twenty six vaccine candidate peptides as described by Carolina Vizcaino et.al. were considered for our in-silico comparisons [20]. These peptides belonged to membrane proteins or secretory proteins in different strains of $M t b$. Sixteen of these 26 peptides showed sequence homology ranging $57-100 \%$ with similar cell surface proteins or secretory proteins of CD11_6 (Mi) (Table 3). Our previous data showed that CD11_6 (Mi) and H37Rv have similar membrane proteins. In this section, similarity percentages indicate that the proteins encoded by strain CD11_6 (Mi) also contains similar vaccine peptides like those derived from different strains of H37Rv-Mtb by Carolina Vizcaino et.al. These sequence homology data may support the potential of strain CD11_6 (Mi) as a vaccine candidate against $M t b$.

Immunization with Mi increases the pool of activated T cells and reduces the Mtb burden in the lungs and spleen

Both memory CD4 T cells and CD8 T cells play a fundamental role in protection against intracellular pathogens like $M t b[21,22] . C D 44^{\mathrm{hi}}, \mathrm{CD} 62 \mathrm{~L}^{\mathrm{hi}}$ and $\mathrm{CD} 127^{\mathrm{hi}}$ are known to be key molecules displayed on the surface of memory T cells [23]. As compared to BCG, we observed that the cells obtained from the animals exposed to $M i$ exhibited significant enhancement in the percentage of CD62L ${ }^{\text {hi }} \mathrm{CD} 44^{\text {hi }}, \mathrm{CD}_{2} \mathrm{~L}^{\mathrm{lo}} \mathrm{CD} 44^{\mathrm{hi}}(p<0.0005), \mathrm{CD} 127^{\text {hi }}$ $(p<0.05)$ and expressing CD4 T cells (Fig. 6), thus indicating that $M i$ induces the generation of central and effector memory CD4 T cells. CD62L ${ }^{\text {hi }} \mathrm{CD} 44^{\text {hi }}$ phenotype represents central memory, whereas $\mathrm{CD} 62 \mathrm{~L}^{\mathrm{lo}} \mathrm{CD} 44^{\mathrm{hi}}$ population represents effector memory [24]. CD4 T cells 


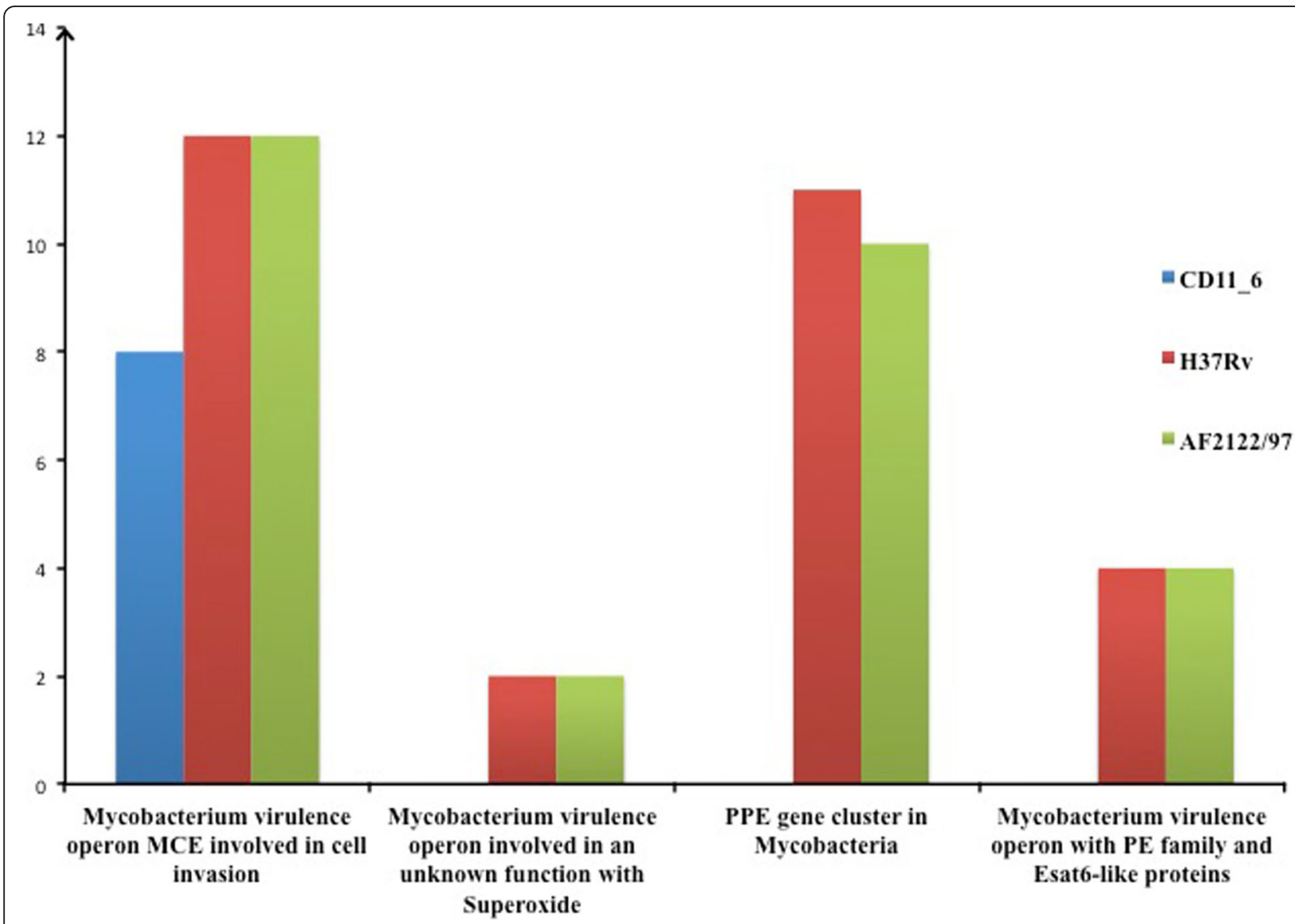

Fig. 4 Comparison of gene homologues present in the Mycobacterium strains involved in invasion and intracellular resistance. Genetic variability was reported in subsystems Mycobacterium virulence operon MCE involved in cell invasion, Mycobacterium virulence operon involved in an unknown function with Superoxide dismutase and PPE gene cluster in Mycobacteria whereas for other subsystems no such difference was reported among three genomes. Thus, for all three genomes, 2 genes were present in subsystem Mycobacterium virulence operon involved in an unknown function with a Jag Protein and YidC and YidD, subsystem Mycobacterium virulence operon possibly involved in quinolinate biosynthesis had 3 genes, Mycobacterium virulence operon involved in DNA transcription had 2 genes, subsystem Mycobacterium virulence operon involved in protein synthesis (SSU ribosomal proteins) had 5 genes, subsystem Mycobacterium virulence operon involved in fatty acids biosynthesis had 2 genes, subsystem Mycobacterium virulence operon involved in lipid metabolism had 2 genes, subsystem Mycobacterium virulence operon involved in protein synthesis (LSU ribosomal proteins) had 3 genes

play a cardinal role in maintaining enduring protection against infection. BCG is known to induce diminished frequency of memory $\mathrm{T}$ cells which may be one of the reasons for its failure to impart long-lasting protection against $M t b$ [6]. These results suggest an important role of $M i$ in elicitation of memory CD4 T cells.

It has been demonstrated that $\beta 2$-microglobulin knock-out mice, which are deficient in MHC class I molecules die rapidly of $M t b$ infection, thus signifying a crucial role of CD8 T cells in protection against Mtb [2527]. Therefore, we next monitored the expansion in the pool of memory CD8 $\mathrm{T}$ cells in the animals immunized with $M i$. Interestingly, in the case of CD8 T cells, both effector $\left(\mathrm{CD} 62 \mathrm{~L}^{\mathrm{lo}} \mathrm{CD} 44^{\mathrm{hi}}\right)$ and central memory $\left(\mathrm{CD} 62 \mathrm{~L}^{\mathrm{hi}} \mathrm{CD} 44^{\mathrm{hi}}\right)$ responses were significantly increased in $M i$ immunized animals as compared to animals immunized with BCG (Fig. 7). Further, a significant increase $(p<0.0005)$ in the percentage of CD127 $7^{\text {hi }}$ expressing CD8 $\mathrm{T}$ cells was also observed in $M i$ immunized animals. Evidence supports the fact that expression of CD127 on CD8 T cells indicates a subset of effector CD8 T cells that successfully develop into fully protective memory. The combination of surface staining for CD127 and CD62L further separates between two functionally distinct memory cell subsets, central memory $\mathrm{T}$ cells $\left(\mathrm{CD} 127^{\mathrm{hi}}\right.$ and $\left.\mathrm{CD} 62 \mathrm{~L}^{\mathrm{hi}}\right)$ and peripheral effector memory $\mathrm{T}$ cells $\left(\mathrm{CD} 127^{\text {hi }}\right.$ and $\left.\mathrm{CD} 62 \mathrm{~L}^{\mathrm{lo}}\right)[28,29]$. The phenotype observed in the $M i$ immunized CD8 T cells is an indicative of central memory, the cells responsible for long-term protection.

Immunization with $M i$ also resulted in significantly ( $p$ $<0.005)$ increased percentage of KLRG1 ${ }^{\text {hi }}$ expressing 


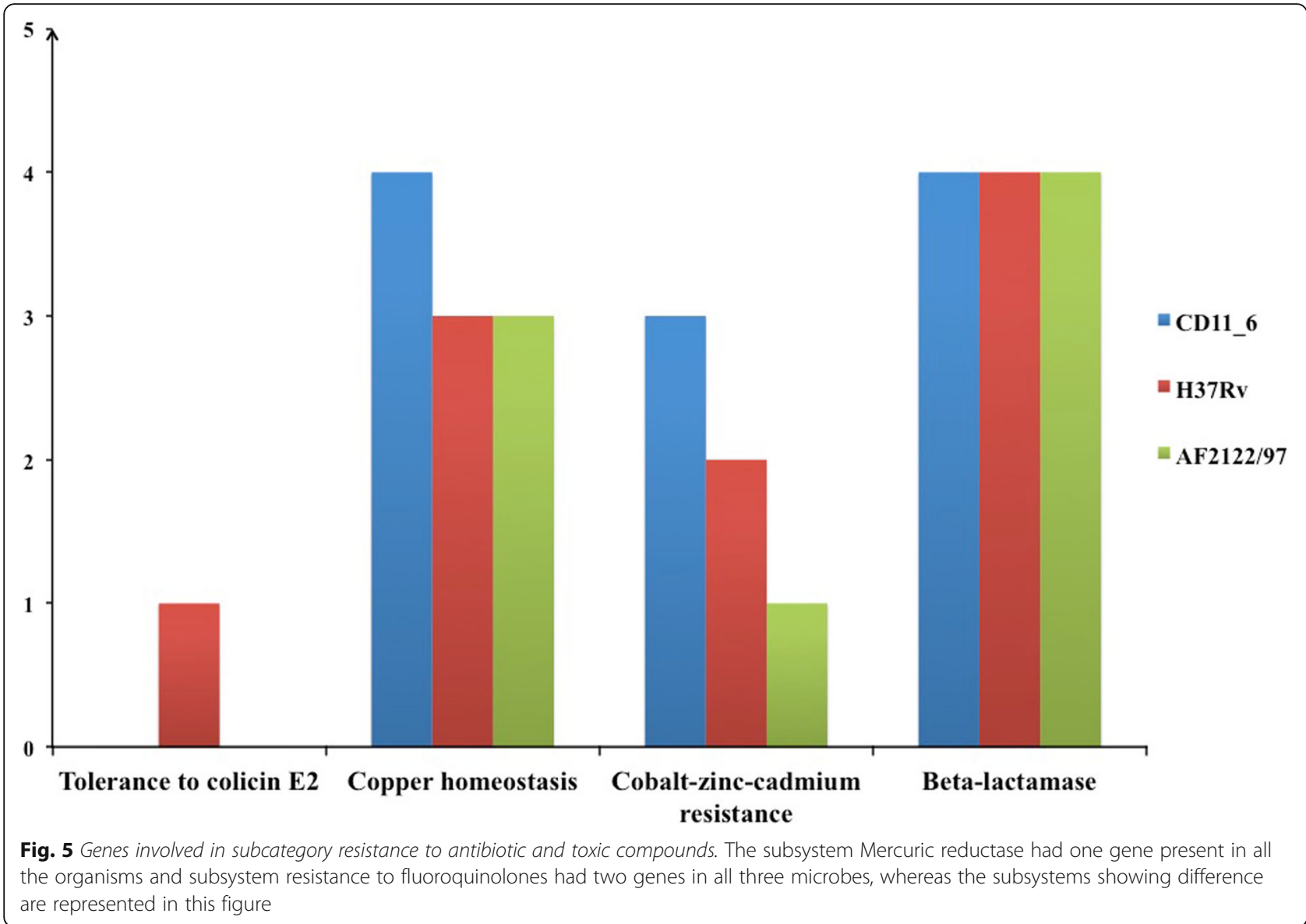

CD8 T cells, as compared to BCG (Fig. 7). KLRG1 is an established marker associated with activated killer CD8 $\mathrm{T}$ cells [30]. $\mathrm{CD}^{+} \mathrm{T}$ cells generated against HIV and Epstein-Barr virus have been shown to have KLRG1 ${ }^{\text {hi }}$ expression, thus demonstrating a potential role of $M i$ in elicitation of CD8 T cells with killer ability [31]. Such cells may be beneficial in sensing and liberating the $M t b$ hidden in the macrophages and providing opportunity to activated macrophages to phagocytose and kill it. Furthermore, we observed decline in the $M t b$ burden in the lungs and spleen of the animals that were vaccinated with $M i$, when compared with placebo (PBS) group. Insignificant change was observed with BCG (Fig. 8). Overall, the results reveal that immunization with $M i$ elicits memory $\mathrm{T}$ cell response better than BCG.

\section{Discussion}

TB is declared as a global emergency in the wake of emergence of multidrug resistance of $M t b$, AIDSpandemic and non-compliance of BCG vaccine [32-34]. Annually, $M t b$ infects 9 million individuals and kills approximately 2 million people. To control TB epidemic, we require urgent and effective prophylactic and/or therapeutic vaccination strategies. Several clinical trials over the years have shown the inadequacy and inconsistency of BCG vaccine worldwide [35]. Additionally, owing to poor efficacy of BCG in TB endemic areas, there is an urgent requisite to develop a new vaccine against TB $[5,6]$. This exigency can be evidenced by the fact that currently there are 14 vaccines in clinical trials. Four of them viz Ad5Ag85A, MVA85A, ChAdOx1.85AMVA85A and MVA85A-IMX313 are in phase I trials; six: RUTI, H56/H4+ IC31, TB/FLU-04 L, ID93 + GLA-SE and MTBVAC are in phase II trials; three: VPM1002, DAR-901 and M72 + AS01E are in phase IIb trials and one: $M$. vaccae in a phase III clinical trial $[36,37]$.

Several efforts are underway for the development of a novel vaccine candidate to replace BCG or boost its efficacy. Live attenuated or killed whole-cell vaccines (WCVs) against $M t b$ exhibit several advantages over protein adjuvant formulations and recombinant vaccines. WCVs possess broad antigen composition, which includes the complete protein repertoire, lipids, carbohydrates, and other moieties that may elicit immune response and protect against $M t b$. Live WCVs induce long-lasting immunological memory and have shown great success against diseases like measles, small pox, yellow fever, polio, etc. Therefore, live 
Table 3 Sequence homology between vaccine candidate peptides of Mtb and Mi

\begin{tabular}{|c|c|c|c|c|c|}
\hline S.No & $\begin{array}{l}\text { Strains of Mycobacterium } \\
\text { tuberculosis }\end{array}$ & $\begin{array}{l}\text { Vaccine candidate peptides } \\
\text { of secretory and membrane } \\
\text { proteins }\end{array}$ & $\begin{array}{l}\text { Similar peptides as vaccine } \\
\text { candidates in } \mathrm{Mi}\end{array}$ & $\begin{array}{l}\text { Name of the protein these } \\
\text { peptides belong }\end{array}$ & $\begin{array}{l}\text { Sequence } \\
\text { homology }\end{array}$ \\
\hline 1. & Rv0200 (+) & LVLLWEGVAINFWLLRRD & ${ }^{45}$ LLITQGMAINAYLARRD ${ }^{61}$ & $\begin{array}{l}\text { Possible membrane protein, } \\
\text { Rv0200 }\end{array}$ & $14 / 17(82 \%)$ \\
\hline 2. & Rv0200 (+) & QAARALRVTLTKRGSGWLV & ${ }^{203}$ QSVLALRLTLAKHDGRWLV ${ }^{221}$ & $\begin{array}{l}\text { Possible membrane protein, } \\
\text { Rv0200 }\end{array}$ & $12 / 19(63 \%)$ \\
\hline 3. & Rv1280C (+) & DGYQDNSGWAYNPEQAKRE & ${ }^{780}$ DGYQDEWAAVLADPDKLRR $^{798}$ & $\begin{array}{l}\text { Nitrite reductase }[\mathrm{NAD}(\mathrm{P}) \mathrm{H}] \\
\text { large subunit }\end{array}$ & $12 / 19(63 \%)$ \\
\hline 4. & Rv3630 & LTRAPLLVPLTAMQGNLIAH & 271 LTRAPLLVPLTALQGNLIAH ${ }^{290}$ & Possible membrane protein & $20 / 20(100 \%)$ \\
\hline 5. & Rv3630 & LTRAPLLVPLTAMQGNLIAH & ${ }^{4}$ LTPLPVLIPLTAAALTLIA ${ }^{22}$ & $\mathrm{Na}(+) \mathrm{H}(+)$ antiporter subunit $\mathrm{D}$ & $13 / 19(68 \%)$ \\
\hline 6. & Rv0418 (+) & LKMAGKTAQDTSFDGRSDYD & ${ }^{388}$ LAEQGKKAHDTGYDGRSDYD ${ }^{407}$ & $\begin{array}{l}\text { Aminopeptidase Y (Arg, Lys, Leu } \\
\text { preference) (EC 3.4.11.15) }\end{array}$ & $14 / 20(70 \%)$ \\
\hline 7. & Rv0418 (+) & LKMAGKTAQDTSFDGRSDYD & ${ }^{389}$ LNLAGKRPAAEEFSGRSDY ${ }^{407}$ & $\begin{array}{l}\text { Aminopeptidase Y (Arg, Lys, Leu } \\
\text { preference) (EC 3.4.11.15) }\end{array}$ & $11 / 19(57 \%)$ \\
\hline 8. & Rv0418 (+) & VAAPADDSPGCSPSDYDRLP & ${ }^{144}$ VPARAEESPGCTVEDYDGL ${ }^{162}$ & $\begin{array}{l}\text { Aminopeptidase Y (Arg, Lys, Leu } \\
\text { preference) (EC 3.4.11.15) }\end{array}$ & $14 / 19(73 \%)$ \\
\hline 9. & Rv0418 (+) & VAAPADDSPGCSPSDYDRLP & ${ }^{28}$ AAADDPPNCTPAD ${ }^{40}$ & Exported protein & 10/13 (76\%) \\
\hline 10. & Rv1022 & DGIANVDNIDDAALSAAGYL & ${ }^{193}$ DGEPSPDNIDDAALSAAGYL ${ }^{212}$ & Lipoprotein LpqU & $17 / 20(85 \%)$ \\
\hline 11. & Rv0566 (+) & TPDRITYRPQLGVLYPSELS & ${ }^{51}$ TPERVTYRPELGVLYPSELS ${ }^{70}$ & Possible membrane protein & $20 / 20(100 \%)$ \\
\hline 12. & Rv0566 (+) & TPDRITYRPQLGVLYPSELS & ${ }^{177}$ DAIAYLPEFGVLYAGDL ${ }^{193}$ & Fumarylacetoacetase (EC 3.7.1.2) & $11 / 17(64 \%)$ \\
\hline 13. & Rv0361 & DAETETVITTSDNDAAVTQ & ${ }^{189}$ SEGRTWLTTHDMDEAVS ${ }^{206}$ & $\begin{array}{l}\text { ABC transporter, ATP-binding } \\
\text { protein }\end{array}$ & 13/18 (72\%) \\
\hline 14. & Rv0361 & RSLDLQFRDDQWKITQSSSN & ${ }^{242}$ RSFDLQFRDNQWKICQS ${ }^{258}$ & $\begin{array}{l}\text { Probable conserved membrane } \\
\text { protein }\end{array}$ & 15/17 (88\%) \\
\hline 15. & $\operatorname{Rv} 1326 \mathrm{c}(-)$ & MSRSEKLTGEHLAPEPAEMA & ${ }^{348}$ ERLTVEHALPSPAEL ${ }^{362}$ & $\begin{array}{l}\text { NTD biosynthesis operon putative } \\
\text { oxidoreductase NtdC }\end{array}$ & $11 / 15(73 \%)$ \\
\hline 16. & $\operatorname{Rv} 1326 \mathrm{c}(-)$ & RFDGTPLYEHSDPKRGEQLD & ${ }^{359}$ RFDGTPLYEHADPHRAEQLD ${ }^{378}$ & $\begin{array}{l}\text { 1,4-alpha-glucan (glycogen) } \\
\text { branching enzyme, GH-13-type } \\
\text { (EC 2.4.1.18) }\end{array}$ & $18 / 20(90 \%)$ \\
\hline
\end{tabular}

attenuated vaccines against $\mathrm{TB}$ may offer promising results.

In a pursuit for a vaccine that can impart protection against $M t b$, we did whole genome sequencing, annotation and analysis of $M i$ to evaluate its safety and suitability for considering it as a vaccine candidate against $M t b$. The virulence status of the $M i$ was checked and compared with $M t b$ and $M b$ by analyzing differences in the genes belonging to VDD in RAST server. Interestingly, $M i$ contains lesser number of virulent genes as compared to $M t b$ and $M b$. In addition, it has antigenic proteins similar to $M t b$. Further, 16 vaccine candidate peptides have been predicted from CD11_6 $(M i)$, making it a suitable vaccine candidate against $M t b$. Live $M i$ is known to induce abscess, hence we have used heat killed $M i$. In addition, HK $M i$ induced significantly better generation of both memory CD4 T cells and CD8 T cells [Figs. 6 and 7], which is a fundamental attribute of a successful vaccine. In contrast, main failure of BCG is its inefficiency to induce enduring memory $\mathrm{T}$ cells and therefore its potency to protect against TB wanes with age in the vaccinated population [6].
Intriguingly, immunization with $M i$ in the experimental model of TB significantly augmented the generation of central and effector memory response in CD4 and CD8 T cells, as evinced by CD62 $\mathrm{L}^{\text {hi }} \mathrm{CD} 44^{\text {hi }}$ and CD62L ${ }^{\mathrm{lo}} \mathrm{CD} 44^{\mathrm{hi}}$, phenotype respectively. The memory CD4 $\mathrm{T}$ cells and CD8 $\mathrm{T}$ cells are known to play a fundamental role in maintaining the enduring immunity and protection against $M t b$. Elicitation of memory CD4 T cells and CD8 $\mathrm{T}$ cells by $M i$ may overcome this snag associated with BCG. As compared to placebo group, we observed decline in the $M t b$ load in the lungs and spleen of the mice vaccinated with $M i$. Based on the memory T cell data, we expect better reduction in $M t b$ growth by $M i$. Contrary to our belief, no significant difference was observed in the $M t b$ burden between $M i$ and BCG immunized groups. Currently, it is difficult to explain this discrepancy. However, our laboratory is extensively working to bolster the efficacy of $M i$ against $M t b$ by changing the dose and the route of inoculation. Overall, the in-silico and in-vivo studies suggest $M i$ as a potential future vaccine candidate against $M t b$. 
BCG

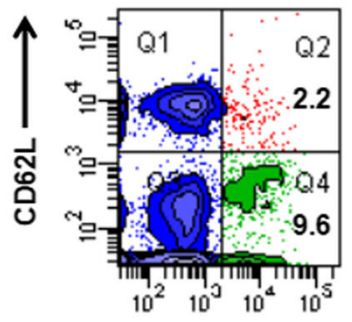

A

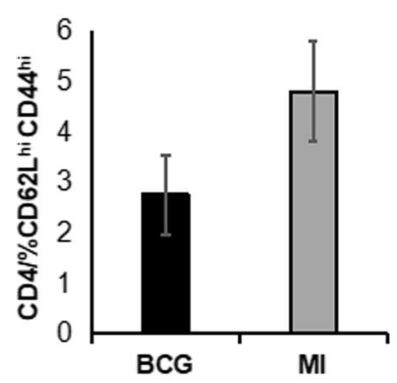

C

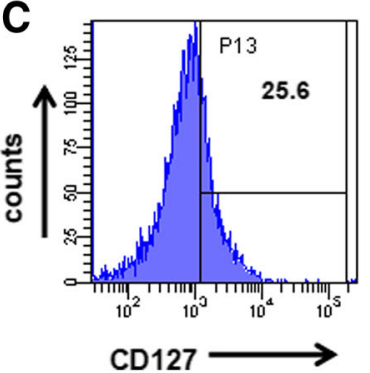

Mi

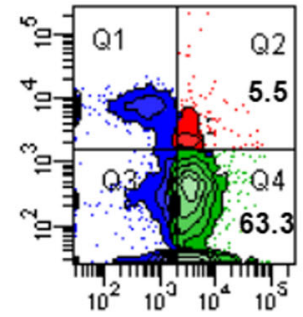

B

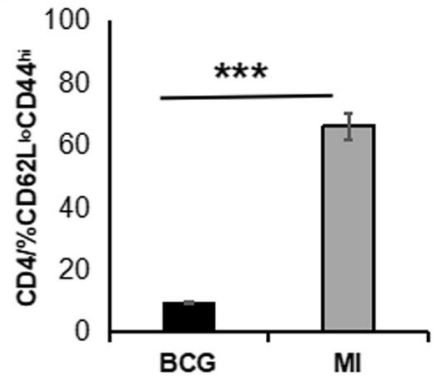

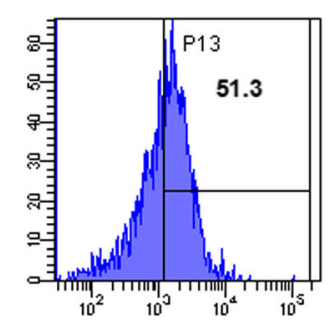

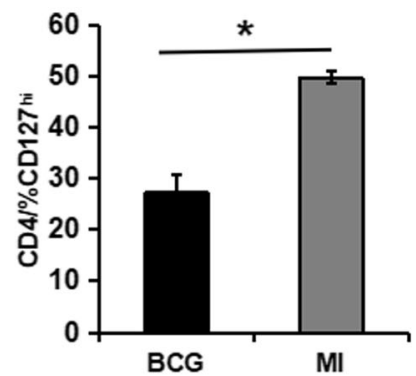

Fig. 6 Immunization with Mi augments the pool of CD44hi, CD62Llo and CD127hi expressing memory CD4 T cells. Lymphocytes isolated from the lungs of mice immunized with Mi and infected with Mtb were cultured in vitro with PPD. The control group of mice were inoculated with BCG. The cells were then monitored for the expression of activation markers (a) CD62L hi $C D 44^{\text {hi }}$; (b) CD62L $L^{\text {lo }} C D 44^{\text {hi }}$; (c) CD127 ${ }^{\text {hi }}$ on CD4 T cells by flow cytometry. Increase in the percentage of $\mathrm{CD} 62 \mathrm{~L}^{\mathrm{hi}} \mathrm{CD} 44^{\mathrm{hi}}, \mathrm{CD} 62 \mathrm{~L}^{\mathrm{lo}} \mathrm{CD} 44^{\mathrm{hi}}$ and $\mathrm{CD} 127^{\mathrm{hi}}$ is depicted as flow cytometry histograms (left panel) and bar diagram (right panel). The data are representative of pooled lymphocytes of 4-5 mice/group obtained from triplicate wells. ${ }^{*} p<0.05,{ }^{* * *} p<0.0005$

\section{Conclusion}

This study highlights the capability of CD11_6 strain of $M i$ to induce the generation of protective memory $\mathrm{T}$ cell response against $M t b$. Using genome mining and annotation results, we depicted the presence of similar genes in $M i$ encoding for surface membrane antigens, membrane transport and cytosolic proteins as of $M t b$. The antigenic repertoire of $M i$ indicated that it has enough potential to protect against $M t b$. We also supported the results with in-vivo experiments; wherein we reported significant increase in the elicitation of memory CD4 T cells and CD8 T cells upon immunization of animals with $M i$. In essence, the present study signifies that $M i$ has the ability to generate effective memory $\mathrm{T}$ cell response against $M t b$ along with eradication of $M t b$ from infected organs. Our results demonstrate that $M i$ has a potential to be used as a vaccine candidate against $M t b$ but extensive future studies are required to gain a deeper understanding in the mechanism of generation of memory $\mathrm{T}$ cell response.

\section{Methods}

Isolation of Mi, DNA extraction, whole genome sequencing, assembly and annotation

Strain CD11_6 was isolated from the duodenal mucosa of a CD patient. The patient was tissue transglutaminase (tTG) IgA-antibody $(\mathrm{Ab})$ positive $(>100 \mathrm{U} / \mathrm{ml})$ with abdominal pain and pain while stool passing. For a purpose to check microbial diversity in duodenum, biopsy samples were collected during endoscopy from the patient at Postgraduate Institute of Medical Education and Research, Chandigarh, India. The biopsy sample was homogenized in sterile phosphate saline (PBS) and 

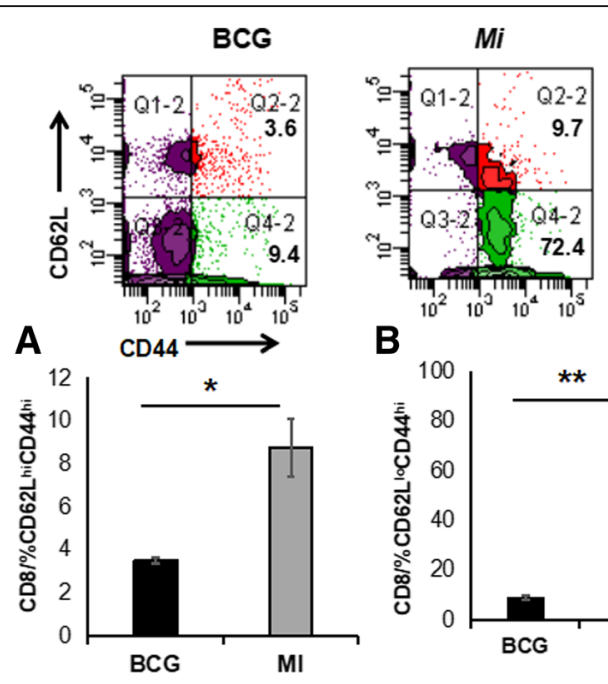

B
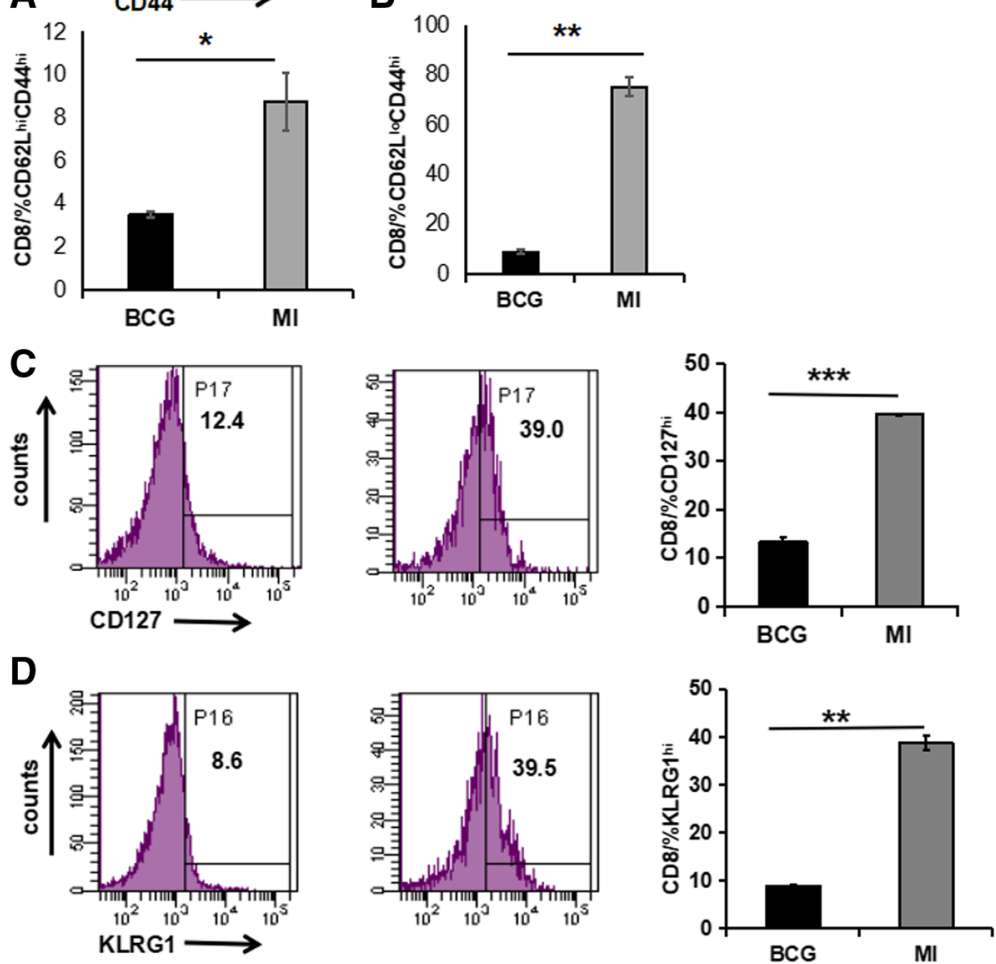

Fig. 7 Inoculation of Mi in animals expands the frequency of effector and central memory CD8 T cells. Lymphocytes isolated from the lungs of mice injected with Mi and exposed to Mtb were cultured in vitro with PPD. The control group of mice was inoculated with BCG. The cells were then monitored for the expression of activation markers (a) CD62L hi $\mathrm{CD}_{4} 4^{\text {hi }}$; (b) CD62 $\mathrm{L}^{\mathrm{lo}} \mathrm{CD} 44^{\mathrm{hi}}$; (c) CD127 ${ }^{\text {hi }}$ (d) KLRG $1^{\text {hi }}$ on CD8 T cells by flow cytometry. Increase in the percentage of $\mathrm{CD} 62 \mathrm{~L}^{\text {hi }} \mathrm{CD} 44^{\text {hi }}, \mathrm{CD} 62 \mathrm{~L}^{\mathrm{L}}{ }^{\mathrm{C}} \mathrm{CD} 44^{\mathrm{hi}}, \mathrm{CD} 127^{\text {hi }}$ and $\mathrm{KLRG} 1^{\text {hi }}$ is depicted as flow cytometry histograms (left panel) and bar diagram (right panel). The data are representative of pooled lymphocytes of $4-5$ mice/group obtained from triplicate wells. ${ }^{*} p<0.05,{ }^{* *} p<0.005,{ }^{* *} p<0.0005$

centrifuged at $4000 \mathrm{rpm}$ for $2 \mathrm{~min}$ to remove debris. The supernatant was serially diluted to plate on to tryptic soy agar (TSA; HiMedia, Mumbai, India) and the plates were incubated aerobically at $37^{\circ} \mathrm{C}$ for $36 \mathrm{~h}$. All individual colonies appearing on the TSA plates were picked and further passaged on to fresh TSA plates to obtain pure colonies. Thereafter, DNA was isolated from the cell mass of pure colonies and 16S rRNA gene sequencing was used to identify microbes. From the patient coded as CD11, total 7 microorganisms were identified, Staphylococcus haemolyticus CD11_1, Pseudomonas monteilii CD11_2, Microbacterium oleivorans CD11_3, Janibacter melonis CD11_4, Dietzia cinnemea CD11_5, Mycobacterium immunogenum CD11_6 and Methylobacterium populi CD11_7. All the strains were sequenced for the purpose of knowing their probable role in pathogenesis of CD. Genomic DNA isolation and amplification was performed as described earlier [38]. Pairwise 16S rRNA gene sequence identity levels were measured by using EzTaxon online server [39]. Mega version 6.0 software was used to create a phylogenetic tree as per the methods described previously [13, 40]. The reference genomes of $M t b$ strain $\mathrm{H} 37 \mathrm{Rv}$ and $M$. bovis $(M b)$ strain AF2122/97 with accession numbers NC_000962.3 and NC_002945.4 respectively, were downloaded from NCBI.

Illumina HiSeq $2 \times 100$ platform was used at C-CAMP to sequence the draft genome of strain CD11_6 (http://ccamp.res.in) next-generation genomics facility, Bengaluru, India. Library preparation and sequencing were performed according to methods described previously [13]. CLC Genomics Workbench 


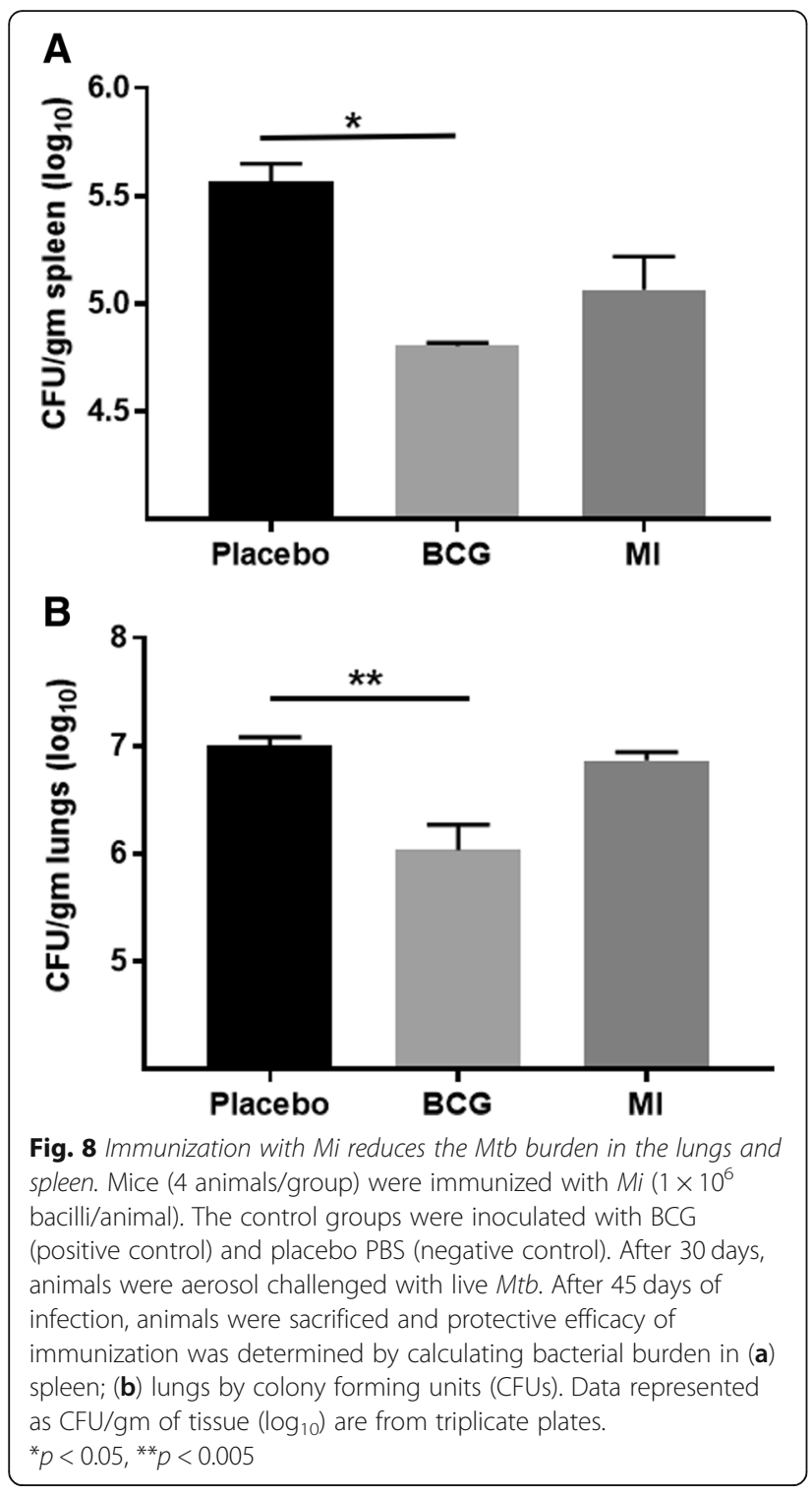

(v7.5.1, CLCbio, Arhus, Denmark) was used for de novo assembly.

Rapid Annotation Subsystem Technology (RAST) server was used to annotate genomes [41-43]. RNAmmer 1.2 was used for identifying ribosomal RNA genes in the genomes [44]. The tRNA and tmRNA genes were identified by ARAGORN [45]. For identifying genome sequence similarity in three genomes, Blast Ring Image Generator (BRIG) software was employed [46]. Comparative genomics approach is based on RAST, an automatic annotation server to predict genes involved for a given function (subsystem). Initially, $M i$ was compared with $M t b$ and then with $M b$ for presence of common and unique genes. The comparative data from three genomes were manually compared, as described previously [13]. More than one person independently validated the manual comparison.
Sequence homology search between the vaccine candidate peptides of $M t b$ and proteome of $M i$

As described by Vizcaino et. al., surface and secretory proteins of virulent strains of $\mathrm{H} 37 \mathrm{Rv}-M t b$ are sufficiently immunogenic and therefore can be exploited as a potential vaccine candidate [20]. Similar peptides were present in Mi strain CD11_6. Surface or secreted proteins are good targets of the immune system. They are considered useful and important in vaccine design. Vizcaino et al. had described 26 vaccine peptides candidates from virulent strains of $\mathrm{H} 37 \mathrm{Rv}-M t b$. For our in silico study, we had considered these 26 peptides as query sequences to search homologous epitopes in the proteome of $M i$. Thus, BLAST search tool of RAST was used to explore presence or absence of such peptides in the annotated protein sequences of strain $M i$. Therefore; sequence homology was determined between the vaccine peptides and proteins of strain CD11_6. The homologous peptides in predicted proteome of $M i$ are inferred as the peptide candidates responsible for providing protection against $M t b$.

\section{Antibodies and reagents}

All standard chemicals and reagents used in the study were purchased from Sigma (St. Louis, Mo., USA), and fluorochrome labeled Abs to CD4-FITC, CD8-APCCy7, CD44-PerCPCy5.5, CD62L-APC and KLRG1-PE were obtained from BD Biosciences (San Diego, CA), unless indicated. RPMI-1640 and FCS were purchased from GIBCO (Grand Island, NY). For culturing of cells, tissue culture grade plastic-ware was purchased from BD Biosciences (Bedford, MA). Purified protein derivative (PPD) of $M t b$ was prepared by standard protocols, as described elsewhere $[47,48]$.

\section{Culturing of Mtb H37Rv and Mi strain CD11_6}

Virulent $M t b$ strain (H37Rv) was was a kind gift from Dr. V. M. Katoch, National JALMA Institute for Leprosy and Other Mycobacterial Diseases, Agra, India. Mtb was cultured in Middle brook 7H9 broth (Difco, Sparks, MD) containing glycerol (0.2\%) and Tween-80 (0.05\%) supplemented with albumin, dextrose and catalase. Viability of bacteria was checked by counting the number of colony-forming units (CFU) by plating onto Middle brook 7H11 medium (Difco, Sparks, MD) supplemented with oleic acid, albumin, dextrose and catalase. $M i$ was cultured in nutrient broth (Himedia, Mumbai, India) at $30{ }^{\circ} \mathrm{C}$ for $48 \mathrm{~h}$ and number of viable bacteria were determined by plating on nutrient agar plates (Himedia, Mumbai, India).

\section{Immunization and infection}

Female C57BL/6 mice (6-8 weeks) were procured from the animal facility of the CSIR-Institute of Microbial Technology, Chandigarh, India. Animals (4-5 mice/ 
group) were immunized with heat killed $M$. immunogenum (HKMi) $\left(1 \times 10^{6}\right.$ bacilli/ animal). The bacteria were diluted in phospate buffered saline (PBS) and administered in animals via subcutaneous route (s.c.) on base of tail. The control groups were also included comprising of mice inoculated with BCG (positive control) and placebo PBS (negative control). After 15 days, a booster dose of $M i$ was administered. Later, animals were aerosol challenged with Mtb (100 CFU/mouse) after 30 days using Inhalation Exposure System (GlasCol, LLC, Terre Haute, IN). After 45 days of infection, animals were sacrificed by cervical dislocation. The lymphocytes were isolated from lungs for immunological assays. Further, $M t b$ load was enumerated in the lungs and spleen by CFU counting.

\section{Cell culture and expression of memory markers on T cells by flowcytometry}

Lungs obtained from experimental and control mice were perfused by chilled PBS, fragmented into small pieces and digested with collagenase $(2 \mathrm{mg} / \mathrm{ml})$ for $30 \mathrm{~min} / 37^{\circ} \mathrm{C}$. The RBCs were lysed with ACK lysis buffer $\left(150 \mathrm{mM} \mathrm{NH}_{4} \mathrm{Cl}, 1\right.$ $\mathrm{mM} \mathrm{KHCO}$ and $0.1 \mathrm{mM} \mathrm{Na}_{2} \mathrm{EDTA}, \mathrm{pH}$ 7.4). The cell viability was measured by trypan blue exclusion method recorded as $>99 \%$. The lymphocytes isolated from lungs $(2 \times$ $10^{5}$ cells/well) were cultured in 96 well U-bottomed microtiter culture plates with RPMI $1640+$ FCS 10\% $(200 \mu \mathrm{l})$ and purified protein derivative (PPD; $25 \mu \mathrm{g} / \mathrm{ml}$ ) for $48 \mathrm{~h} / 37^{\circ} \mathrm{C} /$ $5 \% \mathrm{CO}_{2}$. Later, cells were harvested and washed and stained with fluorochrome labeled $\mathrm{Abs}$ to $\mathrm{CD} 4, \mathrm{CD} 8, \mathrm{CD} 44$, CD62L, CD127 and KLRG1 for $1 \mathrm{~h} / 4{ }^{\circ} \mathrm{C}$. Standard protocols of washing/incubation were followed at each stage. Samples were acquired on FACS-Aria III and analyzed using FACS DIVA software (BD Biosciences, San Jose, CA).

\section{Enumerating protection efficacy of $\mathrm{Mi}$ by CFU counting}

The lung and spleen homogenates were prepared and plating was done on $7 \mathrm{H} 11$ agar plates with 10 -fold serial dilutions. The plates were incubated at $37^{\circ} \mathrm{C} / 5 \% \mathrm{CO}_{2}$ and colonies were enumerated after three weeks of incubation. Results are expressed as $\log _{10}$ colony-forming units (CFUs) per gm of lung tissue.

\section{Statistical analysis}

Graph Pad Prism software program was used to perform all statistical analysis. Statistical testing was performed by one way ANOVA for group analysis and Student's $\mathrm{t}$-test was used for comparing two groups.

\section{Abbreviations}

BRIG: BLAST Ring Image Generator; CD: Celiac disease; CFU: Colony-forming units; HKMi: Heat killed M. immunogenum; Mb: Mycobacterium bovis; Mi: Mycobacterium immunogenum; Mtb: Mycobacterium tuberculosis; PBS: Phosphate buffered saline; PPD: Purified protein derivative; RAST: Rapid Annotation using Subsystem Technology; TB: Tuberculosis; VDD: Virulence, disease and defense

\section{Acknowledgements}

We are thankful to the patients for participating in the study and allowing us to collect the tissues during their surgical intervention. We thank C-CAMP next generation genomics facility for help in obtaining genome sequences. This is IMTECH communication number 023/2017.

\section{Funding}

We are grateful to Council of Scientific and Industrial Research (CSIR), New Delhi, India for funding network project "Man as a Super organism: Understanding the Human Microbiome" [BSC0119] and partly supported by a project, "Expansion and Modernization of Microbial Type Culture Collection and Gene Bank (MTCC)" (Grant No. BSC0402) and Department of Biotechnology (DBT), India (Grant No. BT/PR7368/INF/22/177/2012). Grant BSC0119 provided partial financial support for supplies, reagents, experimental design. Grant BSC0402 and BT/PR7368/INF/22/177/2012 supported data analyses, manuscript writing and laboratory supplies and reagents. AMC was a recipient of fellowship of Indian Council of Medical Research, GK', SKM and GK ${ }^{4}$ of CSIR, India.

Availability of data and materials

The genome sequence of Mycobacterium immunogenum strain CD11_6 has been deposited at DDBJ/EMBL/GenBank under project accession number LQYE00000000. The version described in work is the first version, LQYE00000000.1.

\section{Authors' contributions}

GK' $K^{1}$ AMC, SKM, SN and GK $K^{4}$ performed the experiments. RK provided surgical samples; GK ${ }^{1}, A M C, S K B, J A$ and SM planned and executed experiments, analyzed data and wrote manuscript. GK' , AMC, SKM and JA revised the manuscript. All authors read and approved the final manuscript.

\section{Ethics approval and consent to participate}

The human study protocol was approved by the Institute's Ethics Committee of Postgraduate Institute of Medical Research and Education, Chandigarh, India. An informed written consent was obtained from the participant. CD was diagnosed based on serum IgA anti-tissue transglutaminase antibody [tTG-Ab] and duodenal biopsy suggestive of villous atrophy [49]. The animal study and all experimental protocols were approved by the Institutional Animal Ethical Committee and Institutional Biosafety Committee of Institute of Microbial Technology, Chandigarh, India.

\section{Consent for publication}

Not applicable

\section{Competing interests}

The authors declare that they have no competing interests.

\section{Publisher's Note}

Springer Nature remains neutral with regard to jurisdictional claims in published maps and institutional affiliations.

\section{Author details}

${ }^{1}$ Immunology Laboratory, CSIR- Institute of Microbial Technology, Chandigarh, India. ${ }^{2}$ Department of Endocrinology, Post Graduate Institute of Medical Education and Research, Chandigarh, India. ${ }^{3}$ Department of Biophysics, Panjab University, Chandigarh, India. ${ }^{4}$ Microbial Type Culture Collection and Gene bank (MTCC), CSIR- Institute of Microbial Technology, Chandigarh, India. ${ }^{5}$ Department of Gastroenterology, Post Graduate Institute of Medical Education and Research, Chandigarh, India. ${ }^{6}$ Centre for Biomedical Engineering, Indian Institute of Technology, Ropar, India. ${ }^{7}$ National AgriFood Biotechnology Institute, Mohali, Punjab, India. ${ }^{8}$ Present address: Dr. Shanmugam Mayilraj, Bentoli Agri Nutrition Pvt. Ltd, Chennai, India.

Received: 6 July 2018 Accepted: 18 February 2019

Published online: 20 March 2019

\section{References}

1. Aronson JD. Protective vaccination against tuberculosis, with special reference to BCG vaccine. Minn Med. 1948;31:1336. 
2. Aronson NE, Santosham M, Comstock GW, Howard RS, Moulton LH, Rhoades ER, et al. Long-term efficacy of BCG vaccine in American Indians and Alaska Natives: A 60-year follow-up study. JAMA. 2004;291:2086-91.

3. ten Dam HG. Research on BCG vaccination. Adv Tuberc Res. 1984;21:79-106.

4. Andersen P, Doherty TM. The success and failure of BCG - implications for a novel tuberculosis vaccine. Nat Rev Microbiol. 2005;3:656-62.

5. Fifteen year follow up of trial of BCG vaccines in south India for tuberculosis prevention. Tuberculosis Research Centre (ICMR), Chennai. Indian J Med Res. 1999;110:56-69.

6. Gowthaman U, Rai PK, Khan N, Jackson DC, Agrewala JN. Lipidated promiscuous peptides vaccine for tuberculosis-endemic regions. Trends $\mathrm{Mol}$ Med. 2012;18:607-14.

7. Singh V, Gowthaman U, Jain S, Parihar P, Banskar S, Gupta P, et al. Coadministration of interleukins 7 and 15 with bacille Calmette-Guerin mounts enduring T cell memory response against Mycobacterium tuberculosis. J Infect Dis. 2010;202:480-9.

8. Weiss DW. Vaccination against tuberculosis with nonliving vaccines. I. The problem and its historical background. Am Rev Respir Dis. 1959;80:676-88.

9. Weng $\mathrm{H}$, Huang JY, Meng XY, Li S, Zhang GQ. Adjunctive therapy of Mycobacterium vaccae vaccine in the treatment of multidrug-resistant tuberculosis: A systematic review and meta-analysis. Biomed Rep. 2016;4:595-600.

10. Chander AM, Yadav H, Jain S, Bhadada SK, Dhawan DK. Cross-Talk Between Gluten, Intestinal Microbiota and Intestinal Mucosa in Celiac Disease: Recent Advances and Basis of Autoimmunity. Front Microbiol. 2018;9:2597.

11. Chander AM, Nair RG, Kaur G, Kochhar R, Mayilraj S, Dhawan DK, et al. Genome Sequence of Kocuria palustris Strain CD07_3 Isolated from the Duodenal Mucosa of a Celiac Disease Patient. Genome Announc. 2016:4:e00210-6.

12. Chander AM, Kumari M, Kochhar R, Dhawan DK, Bhadada SK, Mayilraj S. Genome Sequence of Kocuria polaris Strain CD08_4, an Isolate from the Duodenal Mucosa of a Celiac Disease Patient. Genome Announc. 2017;5: e01158-17.

13. Chander AM, Nair RG, Kaur G, Kochhar R, Dhawan DK, Bhadada SK, et al. Genome Insight and Comparative Pathogenomic Analysis of Nesterenkonia jeotgali Strain CD08_7 Isolated from Duodenal Mucosa of Celiac Disease Patient. Front Microbiol. 2017;8:129.

14. Chander AM, Kochhar R, Dhawan DK, Bhadada SK, Mayilraj S. Genome sequence and comparative genomic analysis of a clinically important strain CD11-4 of Janibacter melonis isolated from celiac disease patient. Gut Pathog. 2018;10:2.

15. Chandra H, Yadav JS. T-cell antigens of Mycobacterium immunogenum, an etiological agent of occupational hypersensitivity pneumonitis. Mol Immunol. 2016;75:168-77.

16. Chandra H, Yadav E, Yadav JS. Alveolar macrophage innate response to Mycobacterium immunogenum, the etiological agent of hypersensitivity pneumonitis: role of JNK and p38 MAPK pathways. PLoS One. 2013:8: e83172

17. Okkels LM, Brock I, Follmann F, Agger EM, Arend SM, Ottenhoff TH, et al. PPE protein (Rv3873) from DNA segment RD1 of Mycobacterium tuberculosis: strong recognition of both specific T-cell epitopes and epitopes conserved within the PPE family. Infect Immun. 2003;71:6116-23.

18. Daugelat S, Kowall J, Mattow J, Bumann D, Winter R, Hurwitz R, et al. The RD1 proteins of Mycobacterium tuberculosis: expression in Mycobacterium smegmatis and biochemical characterization. Microbes Infect. 2003;5:1082-95.

19. Berthet FX, Rasmussen PB, Rosenkrands I, Andersen P, Gicquel B. A Mycobacterium tuberculosis operon encoding ESAT-6 and a novel lowmolecular-mass culture filtrate protein (CFP-10). Microbiology. 1998;144(Pt 11):3195-203

20. Vizcaino C, Restrepo-Montoya D, Rodriguez D, Nino LF, Ocampo M, Vanegas $M$, et al. Computational prediction and experimental assessment of secreted/surface proteins from Mycobacterium tuberculosis H37Rv. PLoS Comput Biol. 2010;6:e1000824.

21. Flory CM, Hubbard RD, Collins FM. Effects of in vivo T lymphocyte subset depletion on mycobacterial infections in mice. J Leukoc Biol. 1992:51:225-9.

22. Sakai S, Mayer-Barber KD, Barber DL. Defining features of protective CD4 T cell responses to Mycobacterium tuberculosis. Curr Opin Immunol. 2014;29:137-42.

23. Winslow GM, Cooper A, Reiley W, Chatterjee M, Woodland DL. Early T-cell responses in tuberculosis immunity. Immunol Rev. 2008;225:284-99.

24. Woodland DL, Scott I. T cell memory in the lung airways. Proc Am Thorac Soc. 2005;2:126-31.

25. Flynn JL, Goldstein MM, Triebold KJ, Koller B, Bloom BR. Major histocompatibility complex class Irestricted T cells are required for resistance to Mycobacterium tuberculosis infection. Proc Natl Acad Sci U S A. 1992;89: 12013-7.

26. Harty JT, Tvinnereim AR, White DW. CD8+ T cell effector mechanisms in resistance to infection. Annu Rev Immunol. 2000;18:275-308.

27. Vankayalapati R, Klucar P, Wizel B, Weis SE, Samten B, Safi H, et al. NK cells regulate $\mathrm{CD} 8+\mathrm{T}$ cell effector function in response to an intracellular pathogen. J Immunol. 2004;172:130-7.

28. Huster KM, Busch V, Schiemann M, Linkemann K, Kerksiek KM, Wagner H, et al. Selective expression of IL-7 receptor on memory $T$ cells identifies early CD40L-dependent generation of distinct CD8+ memory T cell subsets. Proc Natl Acad Sci U S A. 2004:101:5610-5.

29. Lv G, Ying L, Ma WJ, Jin X, Zheng L, Li L, et al. Dynamic analysis of CD127 expression on memory CD8 T cells from patients with chronic hepatitis B during telbivudine treatment. Virol J. 2010;7:207.

30. Voehringer D, Blaser $C$, Brawand P, Raulet DH, Hanke T, Pircher H. Viral infections induce abundant numbers of senescent CD8 T cells. J Immunol. 2001;167:4838-43.

31. Bengsch B, Spangenberg HC, Kersting N, Neumann-Haefelin C, Panther E, von Weizsäcker F, et al. Analysis of CD127 and KLRG1 expression on hepatitis C virus-specific CD8+ T cells reveals the existence of different memory T-cell subsets in the peripheral blood and liver. J Virol. 2007;81:945-53.

32. McShane $H$, Jacobs WR, Fine PE, Reed SG, McMurray DN, Behr M, et al. BCG: myths, realities, and the need for alternative vaccine strategies. Tuberculosis (Edinb). 2012;92:283-8

33. Lonnroth K, Castro KG, Chakaya JM, Chauhan LS, Floyd K, Glaziou P, et al. Tuberculosis control and elimination 2010-50: cure, care, and social development. Lancet. 2010;375:1814-29.

34. Gandhi NR, Nunn P, Dheda K, Schaaf HS, Zignol M, van Soolingen D, et al. Multidrug-resistant and extensively drug-resistant tuberculosis: a threat to global control of tuberculosis. Lancet. 2010;375:1830-43.

35. Rodrigues LC, Pereira SM, Cunha SS, Genser B, Ichihara MY, de Brito SC, et al. Effect of BCG revaccination on incidence of tuberculosis in school-aged children in Brazil: the BCG-REVAC clusterrandomised trial. Lancet. 2005:366:1290-5.

36. Ahsan MJ. Recent advances in the development of vaccines for tuberculosis. Ther Adv Vaccines. 2015;3:66-75.

37. Floyd K, Glaziou P, Zumla A, Raviglione M. The global tuberculosis epidemic and progress in care, prevention, and research: an overview in year 3 of the End TB era. Lancet Respir Med. 2018;6:299-314.

38. Mayilraj S, Saha P, Suresh K, Saini HS. Ornithinimicrobium kibberense sp. nov., isolated from the Indian Himalayas. Int J Syst Evol Microbiol. 2006;56:1657-61.

39. Kim OS, Cho YJ, Lee K, Yoon SH, Kim M, Na H, et al. Introducing EzTaxon-e: a prokaryotic $16 \mathrm{~S}$ rRNA gene sequence database with phylotypes that represent uncultured species. Int J Syst Evol Microbiol. 2012;62:716-21.

40. Tamura K, Stecher G, Peterson D, Filipski A, Kumar S. MEGA6: Molecular Evolutionary Genetics Analysis version 6.0. Mol Biol Evol. 2013;30:2725-9.

41. Aziz RK, Bartels D, Best AA, DeJongh M, Disz T, Edwards RA, et al. The RAST Server: rapid annotations using subsystems technology. BMC Genomics. 2008:9:75.

42. Brettin T, Davis JJ, Disz T, Edwards RA, Gerdes S, Olsen GJ, et al. RASTtk: a modular and extensible implementation of the RAST algorithm for building custom annotation pipelines and annotating batches of genomes. Sci Rep. 2015;5:8365.

43. Overbeek R, Olson R, Pusch GD, Olsen GJ, Davis JJ, Disz T, et al. The SEED and the Rapid Annotation of microbial genomes using Subsystems Technology (RAST). Nucleic Acids Res. 2014;42:D206-14.

44. Lagesen K, Hallin P, Rodland EA, Staerfeldt HH, Rognes T, Ussery DW. RNAmmer: consistent and rapid annotation of ribosomal RNA genes. Nucleic Acids Res. 2007:35:3100-8.

45. Laslett D, Canback B. ARAGORN, a program to detect tRNA genes and tmRNA genes in nucleotide sequences. Nucleic Acids Res. 2004;32:11-6.

46. Alikhan NF, Petty NK, Ben Zakour NL, Beatson SA. BLAST Ring Image Generator (BRIG): simple prokaryote genome comparisons. BMC Genomics. 2011;12:402.

47. Andersen P, Askgaard D, Ljungqvist L, Bennedsen J, Heron I. Proteins released from Mycobacterium tuberculosis during growth. Infect Immun. 1991;59:1905-10.

48. Steadham EM, Martin BM, Thoen CO. Production of a Mycobacterium avium ssp. paratuberculosis purified protein derivative (PPD) and evaluation of potency in guinea pigs. Biologicals. 2002;30:93-5.

49. Oberhuber G, Granditsch G, Vogelsang H. The histopathology of coeliac disease: time for a standardized report scheme for pathologists. Eur J Gastroenterol Hepatol. 1999;11:1185. 